Dorota $Z$ dy be I

ORCID: 0000-0003-3322-7570

Akademia Ignatianum w Krakowie

Magda Śliwa

ORCID: 0000-0002-3340-6934

Przedszkole Montessori „Muszelka” w Krakowie

\title{
Język w procesie kształtowania wrażliwości emocjonalnej dziecka - studium empiryczne
}

\section{Language in the Process of Developing Child's Emotional Sensitiveness: Empirical Study}

SLOWA KLUCZOWE

wrażliwość emocjonalna, kompetencje komunikacyine dziecka, decentracja afektywna, komunikacja wspierająca, ięzyk emocji

\section{KEYWORDS}

emotional sensitivity, communicative competence, affective de-centricity, comforting communication, language of emotions

SPI Vol. 23, 2020/4

ISSN 2450-5358

e-ISSN 2450-5366 DOI: 10.12775/SPI.2020.4.008

Nadestano: 15.12. 2019 Zaakceptowano: 12.10 .2020

Miscellanea 
Głównym celem artykułu jest ukazanie metodologicznych konsekwencji przyięcia takiej perspektywy badawczej. W teoretycznej części przedstawiono psychologiczne i językoznawcze vjęcie wrażliwości emocjonalnej jako ważnego obszaru kompetencji komunikacyjnych dziecka. W części badawczej ukazano dziecięca zdolność do formułowania wypowiedzi wrażliwej emocjonalnie w sytuacji konfliktu poznawczego, ti. zderzenia odmiennych sposobów przeżywania tej samej sytuacji komunikacyinej/doświadczenia życiowego przez partnerów dialogu. Wykorzystano w tym celu test Branta R. Burlesona wraz z opracowana przez niego skalą oceny poziomu wrażliwości wypowiedzi wspierającej. W podsumowaniu zwrócono uwagę na konsekwencje zaniedbywania wrażliwości emocjonalnej dziecka przez współczesną edukację.

\section{ABSTRACT}

Emotional sensitivity is a complex, multidimensional concept, entangled in interpersonal relations, linguistic and situational factors. In this article, the main point of attention are cognitive and linguistic aspects of emotional sensitivity defined as an ability to undertake an affective perspective of interlocutor, being able to imagine how he/she perceives and understands a particular communicative context, how he/she interprets the emotional content of the situation. The key to such emotional sensitivity is not only knowledge of linguistic expressive resources, but also - or maybe even primarily - metacognitive monitoring of interaction, and the ability to reflect on one's own communicative effectiveness in terms of "getting tuned" to interlocutor's emotions.

The main aim of this article is to present methodological consequences of such empirical perspective. Theoretical part of the article contains psychological and linguistic perspectives in defining the emotional sensitiveness as an area of children's communicative competence. Empirical part presents the research on children's ability to build emotionally sensitive utterances in the context of cognitive conflict, e.g. the crush of different ways of coping with the same communicative situation/ experience by two different interlocutors. The test designed by Brant R. Burleson was used to elicit children's reaction along with the scale to estimate the level of emotional sensitivity of comforting communication. In summary, the consequences of neglecting child's emotional sensitivity by contemporary education were described. 


\section{Wprowadzenie}

Wrażliwość emocjonalna kojarzy się często ze słabością - osobę wrażliwą można łatwo zranić, dotknąć, stłamsić. „Wrażliwiec” nie ma odpowiedniej siły przebicia, nie potrafi walczyć o swoje, przeżywa doświadczenia za mocno i zbyt długo, nieadekwatnie do siły bodźca. Jednak to właśnie wrażliwość emocjonalna leży u podstaw szeregu kompetencji miękkich, które stale zyskują na znaczeniu we współczesnym, zdominowanym przez komputery i roboty świecie. Najszerzej można ją określić jako obszar tych kompetencji człowieka, które pozwalają na rozpoznawanie własnych i cudzych stanów emocjonalnych i radzenie sobie $\mathrm{z}$ nimi, samoregulację. W takim rozumieniu wrażliwość emocjonalna jest pojęciem szerokim, wielowymiarowym, o nieostrych granicach, usytuowanym na przecięciu pól badawczych filozofii, antropologii, psychologii, pedagogiki i językoznawstwa. Głównym celem artykułu jest przybliżenie czytelnikom poznawczych, emocjonalnych i językowych składników tego pojęcia, a także ukazanie możliwości zastosowania go w metodologii badań nad kompetencją komunikacyjną dzieci, do diagnozowania dziecięcej zdolności do formułowania wypowiedzi wrażliwych na odbiorcę, rozpoznających perspektywę emocjonalną rozmówcy odmienną od własnej, tj. sytuację zderzenia odmiennych sposobów przeżywania tej samej sytuacji komunikacyjnej/doświadczenia życiowego przez partnerów dialogu. Wykorzystano w tym celu test językowy opracowany przez Branta R. Burlesona, który zakłada, że podstawą wrażliwości emocjonalnej jest zdolność do decentracji poznawczo-afektywnej. Przedstawione w tekście badania są częścią szerszego projektu badawczego, na podstawie którego przygotowana została praca dyplomowa Magdy Śliwy

1 Magda Śliwa (2019). Poziom wrażliwości emocjonalnej dzieci sześcio- $i$ ośmioletnich na przyktadzie podopiecznych wybranych placówek edukacyjnych w Krakowie. Praca licencjacka napisana na Wydziale Pedagogicznym Akademii Ignatianum w Krakowie pod kierunkiem dr Doroty Zdybel. 


\section{Poznawcze i afektywne komponenty wrażliwości emocjonalnej}

$\mathrm{Z}$ psychologicznego punktu widzenia istotą „wrażliwości emocjonalnej” jest zdolność organizmu do odczuwania i reagowania na bodźce, przeżywania wrażeń i doświadczania silnych przeżyć psychicznych (WSJP 2019). Włodzimierz Strus (2012: 52) wyodrębnił dwa wzajemnie dopełniające się obszary tak rozumianej wrażliwości. $\mathrm{Z}$ jednej strony wrażliwość jest przejawem poziomu reaktywności emocjonalnej organizmu, która wyraża się w intensywności reakcji na bodziec emocjogenny. Oznacza to, że osoba wrażliwa silniej i częściej reaguje emocjonalnie na otaczającą rzeczywistość, a intensywność jej reakcji jest uzależniona od poziomu stabilności emocjonalnej jednostki. Drugi aspekt wrażliwości emocjonalnej dotyczy zakresu bodźców, które wywołują reakcję emocjonalną jednostki - można go określić mianem „czułości” na czynniki potencjalnie emotogenne. Osoba wrażliwa będzie dostrzegała i reagowała na czynniki delikatne, słabo dostrzegalne lub mało znaczące dla innych. W takim ujęciu wrażliwość emocjonalna ma wyraźnie rys temperamentalny. Aby mogła się stać podstawą stabilności emocjonalnej jednostki, musi zostać obudowana komponentami sprawnościowymi, takimi jak: kontrola emocjonalna (skłonność do regulowania emocji doświadczanych na co dzień) oraz radzenie sobie $\mathrm{z}$ trudnymi emocjami (odporność na stres) (Strus 2012: 58-59).

Pojęcie wrażliwości emocjonalnej bywa przez wielu badaczy utożsamiane z empatią. Według Stownika psychologii empatia to "zastępcza reakcja afektywna na doświadczenia emocjonalne innej osoby, polegająca na odzwierciedlaniu lub naśladowaniu tej emocji. W tym znaczeniu oczywistą implikacją jest fakt, że doświadczenie empatyczne jest dzieleniem z kimś jego emocji”, współodczuwaniem (Reber 2000: 192-193). Jednak, jak wskazują badania, empatia ma składniki zarówno poznawcze, jak i afektywne (Kaźmierczak, Plopa, Retowski 2007: 10-11). Istotą empatii afektywnej są "procesy emocjonalne powstające $\mathrm{w}$ odpowiedzi na zachowanie innych osób (świadome i nieświadome reakcje emocjonalne, będące odzwierciedleniem emocji obserwowanej osoby)" (Ciechomski 2014: 8). Jej podstawą jest zdolność do rekonstruowania cudzych stanów emocjonalnych i współodczuwania, empatycznego podążania za partnerem. Z kolei istotą empatii poznawczej jest zdolność do decentracji, 
czyli rekonstruowania cudzego punktu widzenia, dostrzegania różnic w sposobie interpretacji sytuacji, rozumienia że tę samą sytuację życiową różni uczestniczy mogą postrzegać, rozumieć i przeżywać w zasadniczo odmienny sposób. Bazując na takim rozróżnieniu Kaźmierczak, Plopa, Retowski (2007: 12) opracowali Skalę Wrażliwości Empatycznej, wyodrębniając trzy jej składowe elementy:

a) Przyjmowanie perspektywy, czyli umiejętność i skłonność do spontanicznego przyjmowania cudzego punktu widzenia w codziennych sytuacjach życiowych, zdolność do „wyjścia poza własne egocentryczne ja” w procesie komunikowania się $\mathrm{z}$ innymi ludźmi.

b) Empatyczną troskę, czyli uczucia „zorientowane na innych”, skłonność do współczucia i współodczuwania w stosunku do ludzi dotkniętych niepowodzeniem życiowym, nieszczęściem itp.

c) Osobistą przykrość, czyli uczucia „zorientowane na siebie”, skłonność do przeżywania strachu, niepokoju, przykrości czy dyskomfortu psychicznego w odpowiedzi na silne negatywne doświadczenia (cierpienie) innych ludzi.

Wydaje się zatem, że choć pojęcia wrażliwości emocjonalnej i empatii są sobie bliskie, zazębiają się, nie można ich traktować synonimicznie.

Jeszcze inną perspektywę analizy proponują badacze wywodzący się z psychologii i socjologii komunikacji, gdzie wrażliwość emocjonalna ujmowana jest w kategoriach komunikacji wspierającej, zorientowanej z jednej strony na dostrzeganie i rozumienie uczuć słuchacza, z drugiej zaś na otwieranie się przed innymi, ujawnianie samego siebie, budowanie wzajemnego zaufania (Weber, Johnson, Corrigan 2004; Burleson 2010; Rittenour, Martin 2008). Zdaniem wielu badaczy, u podstaw „emocjonalnej wrażliwości na słuchacza” leży dojrzewanie struktur poznawczych umysłu, odpowiedzialnych za takie czynniki, jak nabywanie teorii umysłu i zdolności do decentracji afektywno-emocjonalnej (Burleson 2010). Mianem „teorii umysłu” określa się w psychologii złożony i wewnętrznie spójny system przekonań przyczynowo-wyjaśniających, służących do interpretowania i przewidywania zachowań społecznych innych ludzi (Białecka-Pikul 2012). Jego podstawą jest świadomość, że przyczyną ludzkich działań jest nie rzeczywistość sama w sobie, ale raczej przekonania 
i wyobrażenia jednostki dotyczące tej rzeczywistości, niezależnie od tego, w jakim stopniu są one zgodne ze stanem faktycznym. Wyjaśniając cudze zachowania, odwołujemy się do sfery przyczynowości psychologicznej, z natury rzeczy niedostępnej bezpośredniej obserwacji, tzn. do uczuć, pragnień, przekonań i intencji rozmówcy, o których wnioskujemy pośrednio, na podstawie uprzednich doświadczeń. Zdolność do rozpoznawania cudzych emocji jest uznawana za integralną część procesu kształtowania się teorii umysłu, opiera się bowiem na interpretacji cudzych stanów wewnętrznych, zwłaszcza w sytuacji niedookreślonej, w której wiedza, uczucia i przekonania uczestników znacząco różnią się od siebie. W takiej sytuacji przyjęcie perspektywy partnera polega na wyobrażeniu sobie, jak on postrzega, rozumie i definiuje konkretną sytuację porozumiewania się, co czuje i dlaczego, w jakim stopniu jego odczucia różnią się od naszych własnych. Tak rozumiana decentracja afektywna (zdolność do zrozumienia i uszanowania cudzych uczuć) odpowiada za trafność odbioru i interpretacji cudzych wypowiedzi, za swoiste dostrojenie się do słuchacza i zrozumienie jego punktu widzenia, stanowiąc tym samym warunek krytyczny efektywnego mówienia o emocjach (szerzej: Burleson 1982; 1984; 2010). Rebecca B. Rubin i Matthew M. Martin określają wrażliwość emocjonalną komunikacji mianem „orientacji na innych" (1994: 36) i definiują jako zdolność do uważnego słuchania, zainteresowanie potrzebami partnera interakcji, dostrzeganie nie tylko tego, co zostało powiedziane wprost, ale też tego, co przemilczane, a także reagowanie na uczucia rozmówcy i dostosowywanie do nich własnych reakcji. Z kolei Malcolm R. Parks (1997: 36) definiuje wrażliwość na słuchacza jako styl komunikacji potwierdzający wizerunek innych (nieoceniający), empatyczny (nienarzucający dystansu), partnerski (niewywyższający się) i zorientowany na rozwiązywanie problemów, a nie kontrolowanie partnera. 


\section{Język jako narzędzie wrażliwości emocjonalnej - perspektywa lingwistyczna $a^{2}$}

W językoznawstwie wrażliwość emocjonalna rozpatrywana jest w kategoriach umiejętności wyrażania emocji w formie wypowiedzi ekspresywnej. Przyjmuje się, że wypowiedź o charakterze ekspresywnym to taka, w której dominuje intencja wyrażania samego siebie, otwierania się przed drugim człowiekiem, w której potrzeba uzewnętrznienia własnych uczuć rządzi formą i kształtem wypowiedzi, podporządkowując sobie inne jej aspekty, nadając ton całości. Jak podkreśla Renata Grzegorczykowa, wypowiedzi ekspresywne „nie są zorientowane na odbiorcę, nie chodzi w nich o poinformowanie kogokolwiek ani o wpłynięcie na odbiorcę, jest to czysta ekspresja woli, emocji lub sądów”, zazwyczaj ujęta w ramę modalną "Czuję...» lub «Czuję się...»" (Grzegorczykowa 1991: 24). Zarazem jednak tego typu wypowiedzi mogą być złożone i wielowarstwowe, przede wszystkim $z$ uwagi na fakt, że nie zawsze intencja ekspresywna jest werbalizowana wprost, bezpośrednio. Jak zauważa Stanisław Grabias, z językowego punktu widzenia możliwe są trzy sposoby uzewnętrzniania się emocji w wypowiedzi (1997: 294). Emocjonalne stany nadawcy mogą:

- przejawiać się w wypowiedzi w sposób nieświadomy, mimowolny, realizowany poza jej znaczeniem - na dobrą sprawę w każdej wypowiedzi zachodzi takie ujawnianie/zdradzanie uczuć nadawcy. Słuchając kogoś i obserwując jego zachowanie w trakcie mówienia, zawsze możemy znaleźć jakieś sygnały pozwalające wnioskować o tym, co czuje nasz rozmówca, w jakim jest nastroju, nawet jeśli on sam nie chce tego ujawniać;

- być wyrażane w sposób świadomy - to znaczy mogą być zawarte implicite w warstwie znaczeniowej wypowiedzi, choć bez bezpośredniego użycia konkretnej nazwy emocji. W tym znaczeniu wyrażamy uczucia (choć ich nie nazywamy wprost) dobierając środki językowe odpowiednio nacechowane

2 Poniższy fragment tekstu został opracowany na podstawie artykułu Doroty Zdybel (2011). Językowa sprawnośc ekspresywna - spoteczno-kulturowe mechanizmy rozwoju, [w:] Spoteczne uwarunkowania dobrostanu w niepetnosprawności, red. K. Markocka-Mączka, Lublin: Wydawnictwo NeuroCentrum, s. 121-137. 
emocjonalnie, np. sformułowanie „Jakie śliczne psiątko!" wyraża zachwyt i akceptację, w przeciwieństwie do „Co za obrzydliwe psisko!”, które oznacza obrzydzenie, wstręt;

- być komunikowane odbiorcy za pomocą istniejących w języku nazw uczuć.

Gama środków i form językowych, służących realizacji ekspresywnej funkcji wypowiedzi, jest niezwykle bogata i zróżnicowana. Różni je znaczenie, stopień złożoności gramatycznej (leksemy - frazeologizmy - zdania) i motywacja użycia (realna bądź metaforyczna), łączy natomiast wspólna funkcja komunikacyjna. Według Iwony Nowakowskiej-Kempnej, mówienie o uczuciach obejmuje (1995: 15-16):

1. nazywanie uczuć - w tym zarówno nazywanie uczuć osoby, która je przeżywa - tzw. experiencera (ja smucę się, tęsknię, wzruszyłem się), jak też nazywanie uczuć osoby, która je wywołuje, tzw. agensa (zasmuciłem kogoś, rozgniewałem go, zirytowałem);

2. nazywanie objawów uczuć - przybierające często postać frazeologizmu, np. „zbladł jak płótno”," zaczerwienił się ze złości”, „zzieleniał z zazdrości”, „,krzywił się”, ,wydął wargi” itp.;

3. nazywanie działań i zachowań związanych z uczuciami, np. „płakał” ze szczęścia, „wrzeszczał” z wściekłości, „tańczył” z radości. Ta grupa środków daje możliwość dokonania pełniejszej, bardziej obrazowej charakterystyki uczuć, z uwzględnieniem stopnia ich nasilenia;

4. nazywanie przeżyć - doznań związanych z danym uczuciem dokonywane z punktu widzenia osoby doświadczającej (experiencera), tj. mówienie o tym, co czuję, czego doznaję, kiedy przeżywam dane uczucie, np. „włosy mi dęba stanęły” (z przerażenia), „dusza mi w pięty uciekła” (ze strachu), „serce mi z piersi wyskakuje" ( $\mathrm{z}$ radości), przy czym wymienione frazeologizmy zachowują swoje znaczenie nawet bez formuły wyraźnie nazywającej uczucie, są kojarzone z danym uczuciem na zasadzie konwencji kulturowej.

Pomimo bogactwa i plastyczności dostępnych w języku środków wyrazu w powszechnej świadomości zakorzenione jest przekonanie, iż mówienie o uczuciach to zadanie bardzo trudne, złożone, a czasami wręcz niewykonalne: „gdy pragniemy przekazać innym ludziom, zwłaszcza tym najbliższym, jakich uczuć doznajemy, gdy chcemy 
«podzielić się» naszymi uczuciami, «pokazać swoje wnętrze», częściej niż kiedykolwiek indziej przeżywamy dojmujące poczucie braku słów, niewystarczalności języka. To, co mówimy, jest bardzo dalekie od tego, co chcielibyśmy powiedzieć” (Pajdzińska 1999: 83). Zdaniem Anny Wierzbickiej, tę zasadniczą trudność w wyrażaniu uczuć tłumaczy ulotna i subiektywna natura przeżyć emocjonalnych: „uczucie to jest coś, co się czuje - a nie coś, co się przeżywa w słowach. W słowach można zapisać myśli - nie można zapisać w słowach uczuć. Myśl jest czymś, co ma strukturę dającą się odtworzyć słowami. Uczucie z natury rzeczy jest pozbawione struktury, a więc niewyrażalne" (za: Pajdzińska 1999: 83). Zapewne dlatego, starając się „ubrać w słowa” własne uczucia, chętnie sięgamy po metafory - metafora pozwala w niekonwencjonalny i obrazowy sposób uchwycić „niewyrażalne”, poprzez odniesienie do obiektów lub zjawisk znanych i oswojonych.

Podsumowując, mimo iż emocji nie przeżywa się w języku, to właśnie język dostarcza najważniejszych środków/narzędzi do ujawniania i wyrażania emocji w procesie komunikacji. Językowa ekspresja emocji jest podstawą budowania bliskich, intymnych relacji z drugim człowiekiem, negocjowania znaczeń emocjonalnych, jakie przypisujemy wspólnym doświadczeniom życiowym. $Z$ drugiej strony, zgodnie z hipotezą Sapira-Whorfa, język niejako zwrotnie wpływa na naszą wrażliwość emocjonalną, tzn. kształtuje nasze spostrzeganie i interpretację doświadczeń emocjonalnych - stanowi rodzaj filtra interpretacyjnego, który rozmówcy nakładają na rzeczywistość dokonując, mniej lub bardziej świadomie, kategoryzacji zjawisk i zdarzeń ze świata uczuć (Schaff 1982: 24). Pięknie ujęła to Olga Tokarczuk:

Świat jest stworzony ze słów. Coś, co nie zostaje opowiedziane, przestaje istnieć i umiera. To, jak myślimy o świecie i - co chyba ważniejsze - jak o nim opowiadamy, ma więc olbrzymie znaczenie. Coś, co się wydarza, a nie zostaje opowiedziane, przestaje istnieć i umiera. Wiedzą o tym bardzo dobrze nie tylko historycy, ale także (a może przede wszystkim) wszelkiej maści politycy i tyrani. Ten, kto ma i snuje opowieść - rządzi (Tokarczuk 2019).

Tę samą prawdę można zastosować do świata emocji, w którego delikatnej i ulotnej warstwie najlepiej dostrzegamy to, co potrafimy nazwać, uchwycić za pomocą języka, zwerbalizować. Nienazwane obszary emocji umykają naszej percepcji, nie poddają się świadomej refleksji i wartościowaniu, a tym samym tworzą podwaliny dla barier 
komunikacyjnych, zarówno w procesie „rozmowy z samym sobą” (autorefleksji nad własnymi przeżyciami), jak i w dialogu z innymi.

\section{Wrażliwość emocjonalna dzieci w sytuacji konfliktu}

\section{poznawczego - studium empiryczne}

Głównym celem przeprowadzonych badań było rozpoznanie dziecięcej umiejętności formułowania wypowiedzi emocjonalnie wrażliwych w sytuacji konfliktu emocjonalno-poznawczego. W artykule przestawiona zostanie tylko niewielka część badań zmierzających do znalezienia odpowiedzi na dwa pytania:

- W jakim stopniu badane dzieci potrafią sformułować wypowiedź wspierającą emocjonalnie rozmówcę w sytuacji konfliktu emocjonalno-poznawczego?

- Czy i w jakim stopniu istnieje związek między poziomem wrażliwości emocjonalnej badanych dzieci a ich wiekiem?

W badaniach udział wzięło 60 dzieci, w tym 30 sześcioletnich oraz 30 ośmioletnich, podopiecznych kilku placówek edukacyjnych w Krakowie. Większość grupy - tj. 55\% stanowiły dziewczynki. Zdecydowana większość dzieci wywodziła się z rodzin pełnych $(78,3 \%)$ o wysokim (46,7\%) lub średnim statusie socjokulturowym (28,3\%). Rodzin o niskiej pozycji społecznej było w badanej grupie tylko 15\%. Zdecydowana większość badanych dzieci rozpoczęła edukację przedszkolną między 3 a 4 rokiem życia (86,7\%).

W celu zweryfikowania umiejętności rozumienia odmiennych emocji rozmówcy (konfliktu emocji) i pocieszania go (dostarczania wsparcia emocjonalnego) wykorzystano trzy zadania opracowane na podstawie testu językowego zaproponowanego przez Burlesona $(2010)^{3}$ :

I. Wyobraź sobie, że Twój najlepszy przyjaciel nie został zaproszony na przyjęcie urodzinowe do Waszego wspólnego kolegi z klasy. Ty zostałeś zaproszony, wszyscy inni zostali zaproszeni, a on nie. Siedzi teraz ze spuszczoną głową i nie chce się z Tobą bawić. Jak myślisz, co czuje Twój przyjaciel? Co mu powiesz, żeby poczuł się lepiej?

3 Tłumaczenie testu, treści wykorzystanych zadań oraz kryteriów oceny ich realizacji - Dorota Zdybel. 
II. Wyobraź sobie, że Twój najlepszy przyjaciel miał kiepski dzień w przedszkolu/szkole - dostał uwagę w dzienniku! Pani niesprawiedliwie posądziła go o to, że w trakcie zabawy zrzucił roślinę z parapetu - doniczka rozbiła się, kwiat się połamał. Ty akurat tego dnia byłeś dyżurnym i wiesz, że kolega tego nie zrobił, ale Pani nie chciała słuchać wyjaśnień. Po zajęciach Twój przyjaciel nie chciał zaczekać na Ciebie w szatni i pobiegł do domu. Jak myślisz, co czuje Twój przyjaciel? Co mu powiesz, żeby poczuł się lepiej?

III. Wyobraź sobie, że Twoja klasa przygotowała przedstawienie mikołajkowe dla rodziców. Ty miałeś powiedzieć wiersz razem ze swoim najlepszym kolegą. Ćwiczyliście ten wiersz wiele razy, ale na przedstawieniu Twój kolega tak się zdenerwował, że zapomniał słów! Siedzi teraz na ławce z dziwną miną, nawet na Ciebie nie patrzy.Jak myślisz, co czuje Twój przyjaciel? Co mu powiesz, żeby poczuł się lepiej?

Odpowiedzi badanych analizowano uwzględniając: a) ogólną liczbę wykorzystanych strategii wsparcia; b) stopień ich zróżnicowania treściowego (liczbę różnych typów zastosowanych strategii) orz c) poziom wrażliwości emocjonalnej wypowiedzi. Burleson wyodrębnia trzy główne typy strategii wsparcia ze względu na stopień ich wrażliwości na istnienie cudzej perspektywy. Jego propozycja została adaptowana dla potrzeb niniejszych badań w nieco zawężonej postaci, nie udało się bowiem zidentyfikować w wypowiedziach dziecięcych wszystkich typów argumentów wspierających wyodrębnionych i opisanych przez Burlesona (tabela 1).

Zgodnie $\mathrm{z}$ intencją Burlesona, powyższy system kodowania zakłada istnienie hierarchicznej relacji między poszczególnymi kategoriami i dzięki temu pozwala nie tylko na różnicowanie poszczególnych strategii na podstawie obecności lub braku określonych cech komunikatu, ale też na ocenę konkretnej strategii jako bardziej wyrafinowanej, subtelnej czy wrażliwej itp., na podstawie jej miejsca w tej hierarchii. Nie znaczy to jednak, że strategie zdefiniowane jako „te, o wyższym poziomie wrażliwości emocjonalnej” w systemie kodowania są także generalnie bardziej efektywne czy skuteczne niż te „mniej wrażliwe”. Wszystko zależy od konkretnej sytuacji, warunków pojawienia się napięcia emocjonalnego, jego przyczyny, osoby odbiorcy itp. Z komunikacyjnego punktu widzenia umieszczenie konkretnej 
strategii w określonym miejscu opisanej hierarchii pozwala jedynie przypuszczać o zakresie znanych jednostce sposobów reagowania czy wzorców zachowań językowych. Bowiem, jak powiada Burleson:

Użycie konkretnego poziomu strategii zakłada zdolność posłużenia się wszystkimi strategiami, które znajdują się na niższych poziomach hierarchii. To znaczy np. że osoba zdolna do zastosowania strategii o wysokim poziomie wrażliwości [...] może w konkretnej sytuacji posłużyć się strategią odwracania cudzej uwagi od źródła stresu (poziom 2c) jeśli uzna, że stan uczuć drugiej osoby jest względnie nietrwały i rozwodzenie się nad nim mogłoby jedynie pogorszyć sprawę (Burleson 1984: 73-74).

Tabela 1. Hierarchiczny system kodowania poziomu wrażliwości emocjonalnej wypowiedzi wspierajqcych

\begin{tabular}{|c|c|}
\hline $\begin{array}{l}\text { Poziom wrażliwości emocjonalnej } \\
\text { wypowiedzi wspierajq̨cej }\end{array}$ & Typy argumentów \\
\hline $\begin{array}{l}\text { I poziom wrażliwości (1 pkt) } \\
\text { - odrzucenie cudzej perspektywy, czyli postawa } \\
\text { egocentryczna, koncentrujqca się na własnym } \\
\text { punkcie widzenia i odczuwania sytuacji }\end{array}$ & $\begin{array}{l}\text { Odrzucenie może mieć charakter dosłowny, wyraźny, } \\
\text { dokonany explicite lub ukryty, pośredni (implicite): } \\
\text { A. Mówca zaprzecza istnieniu uczuć innych niż włas- } \\
\text { ne (To nie będzie już moiq przyjaciółkq). } \\
\text { B. Mówca kwestionuje słuszność cudzych uczuć (Nie } \\
\text { ma się czym denerwować, to tylko przyięcie). } \\
\text { C. Mówca ignoruje cudze uczucia (Będq inne przyię- } \\
\text { cia). }\end{array}$ \\
\hline $\begin{array}{l}\text { II poziom wrażliwości (2 pkt) } \\
\text { - milczqce (pośrednie) rozpoznanie cudzej } \\
\text { perspektywy. Dziecko dostrzega cudze uczucia i/ } \\
\text { lub reaguje na nie pozytywnie, ale nie potrafi ich } \\
\text { nazwać dosłownie, opisać ani wyjaśnić }\end{array}$ & $\begin{array}{l}\text { Dostarczenie akceptacji w sposób pośredni: } \\
\text { D. Mówca próbuje odwrócić uwagę odbiorcy od } \\
\text { nieprzyjemnej sytuacii i uczuć z niq zwiqzanych } \\
\text { (Jak będq moje urodziny, to ja cię zaproszę). } \\
\text { A. Mówca uznaje cudze uczucia, ale nie próbuje po- } \\
\text { móc odbiorcy zrozumieć, dlaczego powstały i jak } \\
\text { sobie z nimi radzić (Przykro mi, że nie zostaleś } \\
\text { zaproszony). } \\
\text { B. Mówca szuka wyjaśnienia poza sferq uczuć, } \\
\text { starając się przezwyciężyć, zredukować uczucie } \\
\text { napięcia emocjonalnego (Może twoje zaproszenie } \\
\text { się zgubiło albo nie było tyle miejsca, żeby zaprosić } \\
\text { całq klasęe). }\end{array}$ \\
\hline
\end{tabular}




\begin{tabular}{|c|c|}
\hline $\begin{array}{l}\text { Poziom wrażliwości emocjonalnej } \\
\text { wypowiedzi wspierajqcej }\end{array}$ & Typy argumentów \\
\hline $\begin{array}{l}\text { III poziom wrażliwości ( } 3 \text { pkt) } \\
\text { - wyraźne rozpoznanie i opisanie cudzej per- } \\
\text { spektywy. Dziecko wyraźnie dostrzega różne } \\
\text { punkty widzenia, uznaje ich istnienie, opisuje } \\
\text { i uzasadnia uczucia drugiej osoby, tzn. próbuje je } \\
\text { pokazać i wyjaśnić, ujać w formę ięzykowa }\end{array}$ & $\begin{array}{l}\text { Mówca próbuje pomóc odbiorcy zrozumieć syłuacię, } \\
\text { znaleźć ogólniejsze wyjaśnienie. Może też sugerować } \\
\text { strategie radzenia sobie z nieprzyjemnymi uczuciami: } \\
\text { G. Mówca wyraźnie rozpoznaje i nazywa cudze } \\
\text { uczucia, ale nie omawia ich źródła ani natury } \\
\text { syłuacji (Wiem, że jest ci przykro, ale jesteś moim } \\
\text { przyjacielem, wiele osób cię lubi. Jak będq moje } \\
\text { urodziny, to ja cię zaproszę). } \\
\text { A. Mówca stara się wyraźnie opisać i wyjaśnić } \\
\text { cudze uczucia (Bardzo mi przykro z powodu tego } \\
\text { przyjęcia, nie chciałem cię urazić wspominając } \\
\text { o tym, ale wiem, że to zrobiłem. To niezbyt zabaw- } \\
\text { ne zostać tak na boku. Może to tylko pomyłka, } \\
\text { porozmawiam z nim, dobrze?). } \\
\text { B. Mówca stara się wyjaśnić cudze uczucia i pomóc } \\
\text { odbiorcy zdobyć do nich dystans, zobaczyć je } \\
\text { w szerszym kontekście, np. na tle uczuć innych } \\
\text { osób (Rozumiem co czujesz, ja też kiedyś nie } \\
\text { zostałem zaproszony na przyięcie i wiem, jak to } \\
\text { boli - możesz czuć się zraniony lub odrzucony). }\end{array}$ \\
\hline
\end{tabular}

Źródło: Burleson 1984: 74-75; †łumaczenie i opracowanie Dorota Zdybel.

Im większy i bogatszy, bardziej zróżnicowany wewnętrznie jest zatem repertuar posiadanych przez daną jednostkę wzorców zachowania, tym bardziej prawdopodobne, że będzie ona bardziej elastyczna, efektywna i wrażliwa w sytuacjach wymagających wsparcia niż osoba o względnie wąskim repertuarze zachowań. Dlatego też przyjęto dodatkowe kryterium analizy wypowiedzi dziecięcych - zróżnicowanie treściowe zastosowanej przez dzieci argumentacji. Do jego oceny przyjęto następującą skalę ocen:

A. niski poziom zróżnicowania treściowego - gdy dziecko wymieniało tylko jeden typ argumentu $\mathrm{w}$ jednej wypowiedzi (1 pkt);

B. przeciętny poziom zróżnicowania treściowego - gdy wypowiedź zawierała dwa różne typy argumentów (2 pkt);

C. wysoki poziom zróżnicowania treściowego - gdy dziecko potrafiło ują́ trzy lub więcej typów argumentów w jednej wypowiedzi (3 pkt).

Łącznie za oba opisane kryteria oceny każde dziecko mogło uzyskać maksymalnie 18 punktów. Wyniki przedstawia poniższa tabela. 
Tabela 2. Ogólny poziom wrażliwości emocjonalnej wypowiedzi w badanych grupach dzieci

\begin{tabular}{|c|c|c|c|c|c|c|c|c|c|c|c|}
\hline \multirow{2}{*}{ 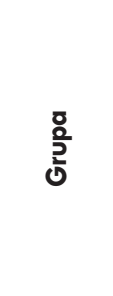 } & \multirow{2}{*}{$\mathbf{z}$} & \multirow{2}{*}{ 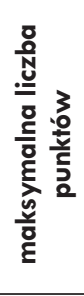 } & \multirow{2}{*}{ 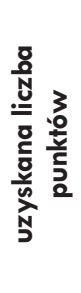 } & \multirow{2}{*}{ } & \multirow{2}{*}{ oீ } & \multirow{2}{*}{ 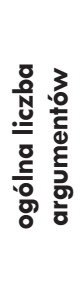 } & \multirow{2}{*}{ 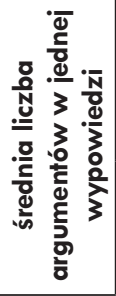 } & \multicolumn{2}{|c|}{$\begin{array}{c}\text { stopień } \\
\text { zróżnicowania } \\
\text { strategii } \\
\text { wsparcia }\end{array}$} & \multicolumn{2}{|c|}{$\begin{array}{c}\text { poziom } \\
\text { wrażliwości } \\
\text { emocjonalnej } \\
\text { wypowiedzi }\end{array}$} \\
\hline & & & & & & & & $\begin{array}{c}\text { liczba } \\
\text { pkt }\end{array}$ & $\%$ & $\begin{array}{c}\text { liczba } \\
\text { pkt }\end{array}$ & $\%$ \\
\hline 6-latki & 30 & 540 & 200 & 6,7 & 37,0 & 90 & 3 & 85 & 31,5 & 115 & 42,6 \\
\hline 8-latki & 30 & 540 & 299 & 10,0 & 55,4 & 121 & 4 & 133 & 49,3 & 166 & 61,5 \\
\hline Ogółem & 60 & 1080 & 499 & 8,3 & 46,2 & 211 & 3,5 & 218 & 40,4 & 281 & 52,0 \\
\hline
\end{tabular}

Źródło: badania własne.

Ogólny poziom wrażliwości emocjonalnej wypowiedzi dziecięcych okazał się zaskakująco niski. Dzieci zdobyły zaledwie nieco ponad 46\% punktów (średnio 8-9 punktów na 18 możliwych). Wyraźnie łatwiejsze okazało się przy tym rozpoznawanie cudzych, odmiennych emocji (wrażliwość emocjonalna - 52\% punktów) niż nadanie temu zrozumieniu formy językowej wypowiedzi wspierającej czy pocieszającej kolegę/koleżankę w niekomfortowej dla niego/ niej sytuacji (zróżnicowanie treściowej wypowiedzi - 40\% punktów). Bardzo wyraźna okazała się tendencja rozwojowa - dzieci 8-letnie radziły sobie z zadaniami zdecydowanie lepiej niż ich młodsi koledzy, zdobywając ogółem ponad 55\% możliwych punktów (w porównaniu do zaledwie 37\% w grupie 6-latków). Ośmiolatki okazały się znacznie bardziej świadome odmiennych emocji kolegi (ponad 61\% punktów w porównaniu do zaledwie $42 \% \mathrm{w}$ grupie młodszej), wykazały się też większą sprawności językową w formułowaniu wypowiedzi wspierającej emocjonalnie (zdobywając ponad 49\% możliwych punktów, w porównaniu do zaledwie $31 \% \mathrm{w}$ grupie dzieci młodszych). Ich wypowiedzi były dłuższe, bardziej zróżnicowane pod względem językowym, lepiej nasycone argumentacją wspierającą trudne emocje kolegi (tabela 2).

Zarazem jednak, jak pokazuje wykres nr 1, sytuacja konfliktu emocjonalnego okazała się wyjątkowo trudna do interpretacji dla wszystkich badanych dzieci - dzieci intuicyjnie wyczuwały, że 
w opisanych sytuacjach kolega/koleżanka czuje się inaczej, gorzej niż one same. Jednak nie potrafiły znaleźć słów, by te odmienne uczucia nazwać i zareagować w sposób wrażliwy, tj. znaleźć sposób na poprawę humoru kolegi. Najdobitniej świadczy o tym odsetek dzieci, które nie potrafiły udzielić żadnej sensownej odpowiedzi na zadane im pytania (20\% w zadaniu 1, kolejne $30 \%$ w zadaniu 2 i aż $31,6 \%$ w zadaniu 3). Poniższy wykres prezentuje wrażliwość emocjonalną wypowiedzi dziecięcych w sytuacjach: (1) zaproszenia na urodziny, (2) niesprawiedliwej uwagi nauczyciela i (3) zapomnianego pod wpływem stresu wierszyka.

Wykres 1. Poziom wrażliwości wypowiedzi wspierajacych w różnych syłuacjach komunikacyinych

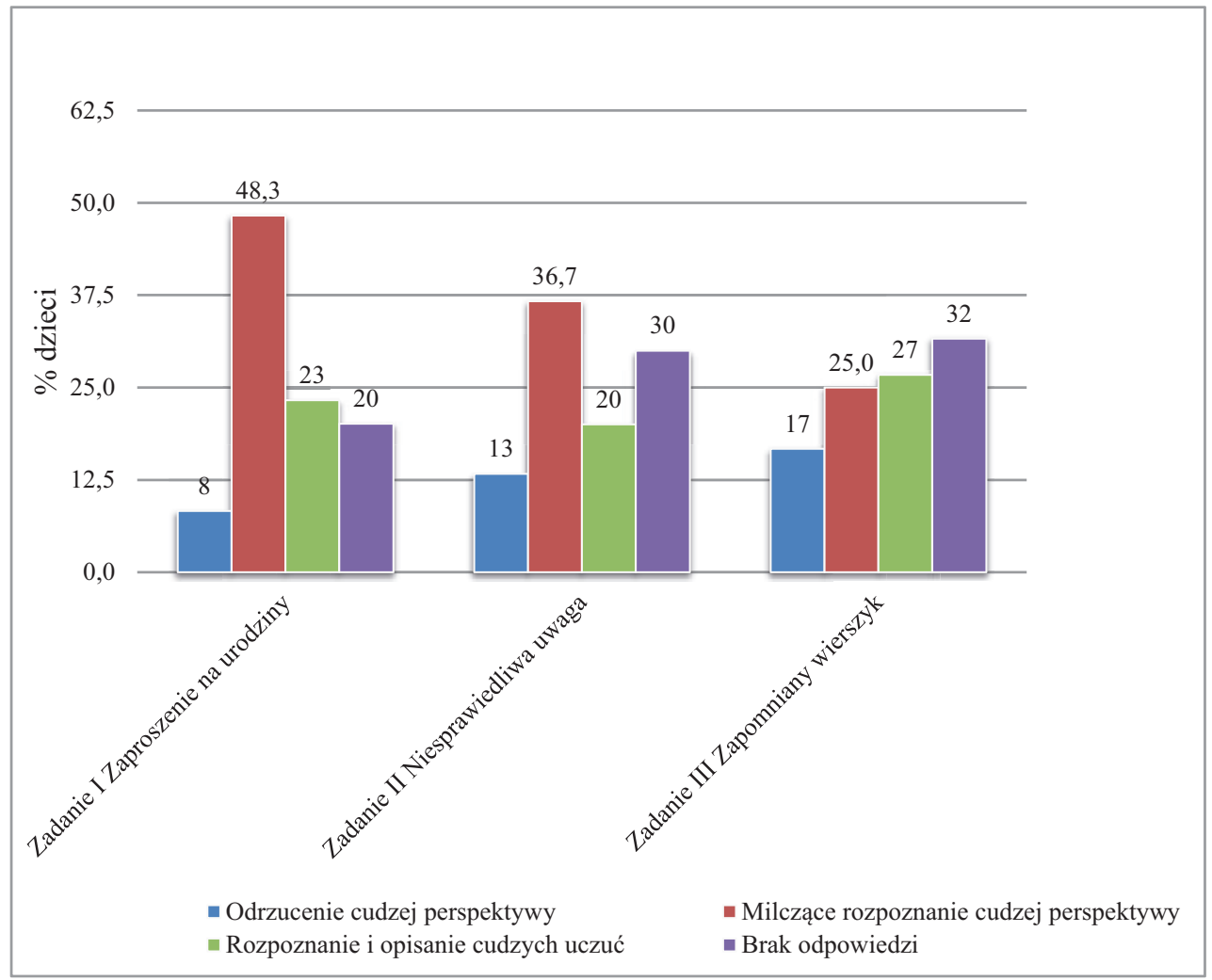

Źródło: badania własne.

Nietrudno zauważyć, że zdecydowana większość reakcji dziecięcych we wszystkich przedstawionych sytuacjach została 
zaklasyfikowana jako tzw. milczące rozpoznanie cudzej perspektywy: dzieci co prawda intuicyjnie wyczuwały cudzy smutek, poczucie odrzucenia, współodczuwały - podążały za przykrymi odczuciami kolegi, starały się pomóc, jednak oferowana w tej sytuacji wypowiedź była raczej próbą odwrócenia uwagi od przykrej sytuacji, zracjonalizowania przyczyn, znalezienia obiektywnego wyjaśnienia, zredukowania napięcia emocjonalnego, ale bez wchodzenia w szczegóły, bez analizowania przyczyn. W zadaniu I aż $48 \%$ badanych dzieci odwołało się do takiej strategii reakcji (w tym aż 50\% sześciolatków i 46,7\% ośmiolatków), w zadaniu II ogólem 36,7\% (w tym 43\% badanych sześciolatków i 30\% ośmiolatków), a w zadaniu III - 25\% dzieci (w tym 23,3\% sześciolatków i 26,7\% ośmiolatków).

Zdecydowanie mniej w obu porównywanych grupach wiekowych było wypowiedzi o wysokim poziomie wrażliwości emocjonalnej świadczących o umiejętności nazwania i opisania trudnych uczuć, wyjaśnienia ich przyczyn, a także zaproponowania sposobu poradzenia sobie z nimi. Taką strategię zastosowało tylko: a) w zadaniu I - ogółem $23 \%$ badanych dzieci ( $w$ tym aż 1/3 ośmiolatków i tylko 13,3\% sześciolatków), b) w zadaniu II - ogółem 20\% badanych (w tym 1/3 ośmiolatków i zaledwie dwójka sześciolatków), c) w zadaniu III tylko 26,7\% badanych (36,7\% ośmiolatków i 16,7\% sześciolatków).

Aby zilustrować różnice $\mathrm{w}$ omawianych strategiach wsparcia emocjonalnego, warto przytoczyć przykłady wypowiedzi dziecięcych. Ponieważ przykłady ilustrujące sytuację I "Zaproszenie na urodziny” zostały już podane $\mathrm{w}$ charakterystyce poziomów kodowania wrażliwości emocjonalnej wypowiedzi (tabela 1), poniżej skoncentrowano się na zadaniu II i III. Nietrudno zauważyć, że poziom wrażliwości budowanych przez dzieci wypowiedzi był nierozerwalnie powiązany z sytuacją mówienia - im bliższa, bardziej znana z doświadczenia sytuacja komunikacyjna, tym łatwiej było zrozumieć uczucia kolegi. Wypowiedzi o najwyższym poziomie wrażliwości zazwyczaj stanowiły mieszankę różnych sposobów argumentowania tak, jakby dzieci intuicyjnie szukały najbardziej skutecznego sposobu pocieszenia kolegi, np. Nie martw sie, następnym razem jak będzie przedstawienie na pewno ci wyjdzie (argument z poziomu III G), (...) jutro na pewno sie fajnie poczujesz; pobawię się z tobą dzisiaj na świetlicy (argument II D) (Pawel, 8 lat). 
Tabela 3. Porównanie poziomów wrażliwości wypowiedzi dziecięcych

\begin{tabular}{|c|c|c|}
\hline $\begin{array}{c}\text { Zadanie/sytuacja } \\
\text { konfliktu emocjonalnego } \\
\text { nadawcy i odbiorcy }\end{array}$ & $\begin{array}{c}\text { Poziom II } \\
\text { Milczqce rozpoznanie cudzej } \\
\text { perspekływy afekływnej }\end{array}$ & $\begin{array}{c}\text { Poziom III } \\
\text { Rozpoznanie i wyraźne opisanie } \\
\text { cudzei perspekływy }\end{array}$ \\
\hline $\begin{array}{l}\text { Zadanie } 2 \\
\text { Niesprawiedliwa uwaga } \\
\text { nauczyciela }\end{array}$ & $\begin{array}{l}\text { - powiedziałabym jej, że powiem } \\
\text { pani jak to się zdarzyło; następ- } \\
\text { nego dnia w przedszkolu będę się } \\
\text { z niq bawić (Karolina, } 6 \text { lat) } \\
\text { - że powiem, że udowodnię pani, } \\
\text { że on tego nie zrobił/pocieszę go } \\
\text { i udowodnię i zrobię tak, żeby pani } \\
\text { mnie słuchała (Adam, 6 lat) } \\
\text { - naprawię za ciebie (Patryk, } 6 \text { lat) } \\
\text { - żebyśmy się razem pobawiły } \\
\text { (Hela, } 6 \text { lat) } \\
\text { - że jakby pani chciała słuchać } \\
\text { wyjaśnienia, to mogę jei powiedzieć } \\
\text { (Nadia, } 8 \text { lat) } \\
\text { - że stłukł przez przypadek } \\
\text { (Filip, } 8 \text { lat) }\end{array}$ & $\begin{array}{l}\text { - nie martw się, ja jutro moge po- } \\
\text { skarżyć pani, że to nie ty to zrobi- } \\
\text { łeś, tylko jakiś kolega cię popchną; } \\
\text { jutro będzie fajny dzień, pani na } \\
\text { pewno ci wybaczy i przeprosi, że } \\
\text { oskarżyła ciebie, chociaż nic nie } \\
\text { zrobiłeś (Paweł, } 8 \text { lat) } \\
\text { - żeby się tym nie martwił, bo to nie } \\
\text { jego wina (Szymon, } 8 \text { lat) }\end{array}$ \\
\hline $\begin{array}{l}\text { Zadanie } 3 \\
\text { Zapomniany wierszyk }\end{array}$ & $\begin{array}{l}\text { - że nie ważne co powie, rodzice } \\
\text { i tak się będa cieszyć, że występuje } \\
\text { (Karolina, } 6 \text { lat) } \\
\text { - po prostu jei przypomnę ten tekst, } \\
\text { albo bym mogła ja rozbawić } \\
\text { (Weronika, } 6 \text { lat) } \\
\text { - chodź ze mnq, może poczujesz się } \\
\text { lepiej (Patryk, } 6 \text { lat) }\end{array}$ & $\begin{array}{l}\text { - nie martw się, czasem ja też } \\
\text { tak mam i zapominam tekstu } \\
\text { (Tymon, 6 lat) } \\
\text { - żeby uwierzył w siebie } \\
\text { (Ludwik, } 6 \text { lat) } \\
\text { - że to nie ona zepsuła występ, } \\
\text { po prostu miała tremę i tak się } \\
\text { skrepowała, że zapomniała tekstu } \\
\text { (Ola, } 8 \text { lat) } \\
\text { - mogłabym jei powiedzieć, że ten } \\
\text { tekst był naprawdę trudny i miała } \\
\text { prawo zapomnieć tego słowa } \\
\text { (Hania, } 8 \text { lat) } \\
\text { - że to jest trema i tak czasami się } \\
\text { zdarza, że człowiek zapomina } \\
\text { tekstu (Zuzia, } 8 \text { lat) }\end{array}$ \\
\hline
\end{tabular}

Źródło: badania własne.

\section{Podsumowanie}

Rozwój wrażliwości emocjonalnej dzieci jest procesem złożonym i wieloaspektowym, uwikłanym w czynniki poznawcze, społeczne i językowe. $\mathrm{W}$ procesie tym równie istotne jest osiąganie zdolności do decentracji poznawczo-afektywnej, jak i uczenie się kodów językowych/kulturowych, za pomocą których emocje są wyrażane 
i komunikowane. Edukacja pełni w tym procesie rolę szczególną, nie tylko dostarcza wzorców poprawnego mówienia (Bower, Casas 2016), ale też tworzy sytuacje komunikacyjne, okazje do uczenia się języka emocji, kierując uwagę dziecka na te aspekty komunikacji, które wymagają empatycznego zrozumienia i odzwierciedlenia, uwzględnienia w wypowiedzi (Paulus, Wörle, Christner 2020).

Badania wskazują, że rozwój językowych umiejętności dostarczania wsparcia emocjonalnego podlega podobnym uwarunkowaniom, co nabywanie innych umiejętności prospołecznych (Conte, Grazzani, Pepe 2018; Bower, Casas 2016). Za szczególnie istotne uznaje się przy tym wsparcie edukacyjne, zarówno rodziców (Giner Torréns, Kärtner 2019), jak i nauczycieli (Gardner, Stephens-Pisecco 2019), tj. modelowanie zachowań dzieci, ciepło i responsywność zachowań dorosłych, obdarzanie uwagą rozmówcy, nazywanie jego uczuć i ich subtelnych odcieni (Yudina, Kotova 2017). Dzieci, które mają okazję obserwować takie zachowania dorosłych, jak: bezinteresowne pomaganie innym, dzielenie się zasobami, szacunek dla uczuć rozmówcy czy pocieszanie w sytuacji trudnej emocjonalnie, szybciej uczą się zarówno zachowań prospołecznych, jak strategii językowych leżących u ich podstaw. $Z$ drugiej strony, doświadczanie wsparcia emocjonalnego ze strony innych pomaga wzmocnić dziecięcą odporność psychiczną ( $\mathrm{Si}-$ korska, Adamczyk-Banach, Polak 2019; Gardner, Stephens-Pisecco 2019), potrzebną w radzeniu sobie z porażką i frustracją w kontaktach rówieśniczych, przepracowywaniu trudnych emocji i osiąganiu równowagi psychicznej. Wielu badaczy wskazuje, że budowanie odporności i siły psychicznej dziecka jest jednym z kluczowych zadań współczesnej edukacji, mocno niedocenianym przez nauczycieli.

Wydaje się, że łącznikiem pomiędzy dziecięcą zdolnością do rozumienia cudzej odmiennej perspektywy emocjonalnej a zdolnością do mówienia o niej w sposób wrażliwy, podążający za słuchaczem i dostarczający mu wsparcia emocjonalnego, jest świadomość metajęzykowa, rozumiana jako zdolność do podejmowania refleksji nad skutecznością, precyzją i perswazyjnością własnych wypowiedzi. Jak się czuje mój rozmówca, co przeżywa, jak rozumie i interpretuje sytuację? Jak to, co powiedziałem, wpłynęło na jego emocje? Jak inaczej mógłbym to powiedzieć? Co ja sam chciałbym usłyszeć w takiej sytuacji? Tego typu refleksja to początek rozwoju świadomości metajęzykowej, która z kolei zwrotnie wpływa na to, jak dziecko postrzega 
emocjonalny, relacyjny, ukryty wymiar komunikacji międzyludzkiej, na ile stara się zrozumieć potrzeby i intencje partnera rozmowy, dostrzegając, że może on czuć i rozumieć zdarzenie zupełnie inaczej. Już sam fakt, że zaczynamy się nad tym zastanawiać sprawia, że bardziej uważnie dobieramy słowa. Bo choć dar wrażliwości emocjonalnej - dostrzegania cudzych uczuć nawet tam, gdzie rozmówca stara się ich nie ujawniać - jest nam niejako „dany”, zakodowany w mechanizmach rozwoju decentracji poznawczo-afektywnej, to już sztuka mówienia o tych uczuciach w sposób wrażliwy, tj. tak, by pozytywnie wpływać na rozmówcę, pocieszać, rozśmieszać, dostarczać wsparcia i rady, sięgać po coraz bardziej wyrafinowane sposoby i strategie ekspresywne, dana jest tylko nielicznym - tym, którzy przeszli odpowiedni trening edukacyjny (Paulus, Wörle, Christner 2020).

\section{Bibliografia}

Białecka-Pikul M. (2002). Co dzieci wiedza o umyśle i myśleniu. Badania i opis dziecięcej reprezentacji stanów mentalnych, Kraków: Wydawnictwo Uniwersytetu Jagiellońskiego.

Bower A., Casas J. (2016). What Parents Do When Children are Good: Parent Reports of Strategies for Reinforcing Early Childhood Prosocial Behaviors, "Journal of Child and Family Studies", t. 25, nr 4, s. 1310-1324, https:// doi.org/10.1007/s10826-015-0293-5.

Burleson B.R. (1982). The Development of Comforting Communication Skills in Childhood and Adolescence, "Child Development”, t. 53, nr 6, s. 15781588, DOI: $10.2307 / 1130086$.

Burleson B.R. (1984). Comforting Communication, [w:] Communication by Children and Adults. Social, Cognitive, and Strategic Processes, red. H.E. Sypher, J.L. Applegate, Beverly Hills (CA)-London-New Delhi: Sage Publications, s. 63-104.

Burleson, B.R. (2003). Emotional Support Skills, [w:] Handbook of Communication and Social Interaction Skills, red.J.O. Greene, B.R. Burleson, Mahwah (NJ): Lawrence Erlbaum, s. 551-594.

Burleson B.R. (2010). Explaining Recipient Responses to Supportive Messages: Development and Tests of a Dual-process Theory, [w:] New Directions in Interpersonal Communication Research, red. S.W. Smith, S.R. Wilson, Thousand Oaks (CA): Sage Publications, s. 159-179.

Ciechomski M. (2014). Wychowanie do empatii - opracowanie i ewaluacja programu edukacyjno-wychowawczego rozwijajacego empatię u dzieci w wieku 9-10 lat, Warszawa [konspekt rozprawy doktorskiej]. 
Conte E., Grazzani I., Pepe A. (2018). Social Cognition, Language, and Prosocial Behaviors: A Multitrait Mixed-Methods Study in Early Childhood, „Early Education and Development”, t. 29, nr 6, s. 814-830, http:// dx.doi.org/10.1080/10409289.2018.1475820.

Gardner R.L., Stephens-Pisecco T.L. (2019). Fostering Childhood Resilience: A Call to Educators, „Preventing School Failure”, t. 63, nr 3, s. 195-202, https://doi.org/10.1080/1045988X.2018.1561408.

Giner Torréns M., Kärtner J. (2019). Affliation Motivates Children's Prosocial Behaviors: Relating Helping and Comforting to Imitation, „Social Development”, t. 28, nr 3, s. 501-513. https://doi.org/10.1111/sode.12357

Grabias S. (1997). Jezyk w zachowaniach spotecznych, Lublin: Wydawnictwo UMCS.

Grzegorczykowa R. (1991). Problem funkcji jezzyka i tekstu w świetle teorii aktów mowy, [w:] Język a kultura, t. 4, red. J. Bartmiński, R. Grzegorczykowa, Wrocław: Wydawnictwo „Wiedza o Kulturze”, s. 11-28.

Kaźmierczak M., Plopa M., Retowski S. (2007). Skala Wrażliwości Empatycznej, „Przegląd Psychologiczny”, t. 50, nr 1, s. 9-24.

Nowakowska-Kempna I. (1995). Konceptualizacja uczuć w języku polskim. Prolegomena, Warszawa: Wyższa Szkoła Pedagogiczna Towarzystwa Wiedzy Powszechnej.

Pajdzińska A. (1999). Jak mówimy o uczuciach? Poprzez analize frazeologizmów do jezzykowego obrazu świata, [w:] Jezykowy obraz świata, red. J. Bartmiński, Lublin: Wydawnictwo UMCS, s. 83-101.

Paulus M., Wörle M., Christner N. (2020). The Emergence of Human Altruism: Preschool Children Develop a Norm for Empatby-based Comforting, "Journal of Cognition and Development”, t. 2, nr 1, s. 104-124, http:// dx.doi.org/10.1080/15248372.2019.1693375.

Parks M.R. (1997). Communicative Competence and Interpersonal Control, [w:] Handbook of Interpersonal Communication, red. M.L. Knapp, G.R. Miller, Beverly Hills (CA): Sage Publications, s. 589-618.

Reber A. (2000). Stownik psychologii, przeł. B. Janasiewicz-Kruszyńska i in., Warszawa: Wydawnictwo Naukowe Scholar.

Rittenour Ch.E., Martin M.M. (2008). Convergent Validity of the Communication-based Emotional Support Scale, „Communication Studies”, t. 59, nr 3, s. 235-241, https://doi.org/10.1080/10510970802257671.

Rubin R.B., Martin M.M. (1994). Development of a Measure of Interpersonal Communication Competence, „Communication Research Reports”, t. 11, nr 1, s. 33-44, https://doi.org/10.1080/08824099409359938.

Schaff A. (1982). Wstęp do polskiego wydania, [w:] B.L. Whorf, Język, myśl, rzeczywistość, przeł. T. Hołówka, Warszawa: PIW, s. 5-31.

Sikorska I., Adamczyk-Banach M., Polak M. (2019). Zasoby odporności psychicznej dziecka - co wiedzq o nich rodzice i nauczyciele, „Edukacja Elementarna w Teorii i Praktyce”, t. 14, nr 52, s. 23-39, DOI: 10.35765/ eetp.2019.1452.02. 
Strus W. (2012). Dojrzatośc emocjonalna a funkcjonowanie moralne, [Stare Kościeliska]: Wydawnictwo Liberi Libri.

Tokarczuk O. (2019). Wyktad noblowski „Czuty narrator”, https://www. rp.pl/Kultura/191209471-Czuly-narrator-Pelny-tekst-noblowskiego-wykladu-Olgi-Tokarczuk.html [dostęp: 7.12.2019].

Wielki Stownik Jezzyka Polskiego (WSJP), https://wsjp.pl/index.php?id_ hasla $=7395 \& i d \_z n a c z e n i a=1907812 \& \mathrm{l}=27 \&$ \&ind $=0$ [dostęp: 12.12.2019]

Wierzbicka A. (1999). Jezzyk - umyst - kultura, Warszawa: Wydawnictwo Naukowe PWN.

Weber K., Johnson A., Corrigan M. (2004). Communicating Emotional Support and Its Relationship to Feelings of Being Understood, Trust, and Selfdisclosure, „Communication Research Reports”, t. 21, nr 3, s. 316-323, DOI: $10.1080 / 08824090409359994$.

Yudina T.O., Kotova T.N. (2017). Empathic Responding in Toddlers: The Role of Experience and Observation of Comforting Behavior, „Psychology. Journal of the Higher School of Economics", t. 14, nr 2, s. 262-276, DOI: 10.17323/1813-8918-2017-2-262-276.

Zdybel D. (2011). Jezzykowa sprawnośc ekspresywna - spoteczno-kulturowe mechanizmy rozwoju, [w:] Spoteczne uwarunkowania dobrostanu w niepetnosprawności, red. K. Markocka-Mączka, Lublin: Wydawnictwo Neuro-Centrum, s. 121-137.

\section{ADRES DO KORESPONDENCJI}

\section{Dr Dorota Zdybel}

Akademia Ignatianum w Krakowie

Instytut Nauk o Wychowaniu

e-mail: dorota.zdybel@ignatianum.edu.pl

Lic. Magda Śliwa

Przedszkole Montessori „Muszelka” w Krakowie

e-mail: madziasliwa13@gmail.com 